\title{
Corruption in Russia: Cause and Effect Relations
}

\author{
Yana V. Gaivoronskaya ${ }^{1} \&$ Tatiana V. Filonenko ${ }^{1}$ \\ ${ }^{1}$ Far-Eastern Federal University, Law School, theory and history of law department, Russian Federation \\ Correspondence: Yana V. Gaivoronskaya, Far-Eastern Federal University, Law School, theory and history of law \\ department, Russian Federation. Tel: 79-02-506-6062. E-mail: yannavlad@gmail.com
}

\author{
Received: December 4, 2014 Accepted: February 4, 2015 Online Published: May 16, 2015 \\ doi:10.5539/ass.v11n13p206 URL: http://dx.doi.org/10.5539/ass.v11n13p206
}

\begin{abstract}
One of the main problems international community faces today is corruption. Along with organized crime, human trafficking and many other similar issues corruption has become exceedingly pressing in recent years.

It is generally known that corruption along with extortion is one of most acute problems that undermine social and economic development, democracy and moral values of the society. The main aim of this article is to summarize and analyze causes of corruption and effect relations that give rise to this social event.
\end{abstract}

Keywords: abuse, corruption dependency, licensing procedures, system of public administration, corruption-related defects in the rule of law, corruption management, anti-corruption policy

\section{Introduction}

The present article has been prepared using methods of statistical analysis, social research and comparative legal analysis.

The author deems that developing anti-corruption action must begin with scrutinizing study of its causes in a given society. We think that causes of corruption constitute a unique complex of factors in each country. Thus, efficiency of anti-corruption actions directly depends on how such actions address causes of corruption in a specific social and cultural environment. That's why the main method of this research is eliciting factors that give rise to corruption.

\section{Discussion and Results}

Corruption has been around for a long time and is taken for granted in many countries.

United Nations Secretary General K. Annan aptly compared corruption unto social "plague" at the General Assembly session at which UN Convention against corruption was passed; all contemporary societies are affected with this epidemic: "Corruption undermines democracy and rule of law that results in violation of human rights, distorts market mechanisms, impairs standard of life, conduces organized crime, terrorism and other threats to the international safety. This very dangerous phenomenon exists in all countries - large and small, prospering and poor..." (Note 1)

The problem of corruption is getting more threatening both in Russia and in the global community. It is widely spread in all classes of the society and in all branches of government. Russia takes one of the leading places among countries of the world based on corruption level.

It order to combat, elicit and prevent it, we need to precisely define what it is.

The word "corruption" originates from a Latin word "corruption" - bribery, which means destruction or breach. This word is a combination of Latin words "corei" - several participants in a binding legal relation related to a single object of dispute and "rumpere" which mean "breach something", in particular, breach of ethical norms by individuals in order to gain profit. (Note 2)

In accordance with the current Russian legislation (Federal statute "On counteracting corruption" dated December 25, 2008) corruption is abuse of one's official position, giving a bribe, accepting a bribe, abusing one's authorities, trading in influence or a different illegal use of an individual's official position in spite of legitimate interests of the society and state in order to derive benefit in the form of money, valuables, other property or property-related services, other property rights for oneself or third parties or in the form of illegal access to a benefit though other individuals, as well as performing the stated actions on behalf and for the benefit 
of a legal entity.

One of main signs of corruption as an abusive practice is its peculiar mechanism constituting one of the following actions:

bilateral transaction in course of which one party - an officer in a state of a different service (corrupt official) illegally "sells" to legal entities or individuals his official authorities or services grounded in the powers pertaining to his position, opportunities and connections relating to it, while the other party (the corrupter) acts as a buyer and is permitted to use the state or a different structure to pursue its own goals (to gain profit, to obtain and maintain certain benefits, avoid social control, liability stipulated by law, etc.);

Extortion of a bribe or additional remuneration by a public official from legal entities or individuals for fulfilling (or failure to fulfill) legal or illegal actions;

Active bribery of public officials by individuals or legal entities at their own initiative often aggravated by psychological pressure onto the former.

An important aspect of corruption is diversity of its subjects; on the one part, these are often public officials and other officers both of public and private sector, on the other hand - these are any physical entities and individual.

Collectively these subjects form a peculiar corruption network. Experts deem that this corruption network consists of three components:

Commercial and financial structures and their representatives exercising the benefits gained though acts of corruption, thus transforming them into an additional income;

Group of public and non-public authorities that grant such benefits for a fee and ensure protection for corrupters when certain decisions are made;

Group that defends corruption consisting of public authorities from law enforcement and surveillance agencies.

Based on data published by Transparency International, Russia takes $127^{\text {th }}$ place of out 175 in total in Corruption Perception Index. In 2012 it took $133^{\text {rd }}$ place out of 174 countries (Note 3).

Experts deem that currently corruption is one of the most profitable and highly organized businesses in Russia; its turnover equals about 300 billion dollars per year. About 1 trillion rubles gets lost annually in the system of state procurement only. Based on data from the Bank of Russia 35 billion dollars were pulled out last year though so called fallible financial transactions. In fact corruption in our country is not evil; it is a factor of degradation for the state. Sociology shows that its extent has surpassed the social "pain threshold". Although results of counteracting corruption are becoming more visible to the population, absolute majority of Russians 75\% from those sampled by Russian National Public Opinion Research Center in November 2013 state that the level of corruption in the Russian society is very high (Note 4).

In the public opinion, most corrupt area is local administration (in the opinion of $36 \%$ of respondents) and State Traffic Safety Inspection (STSI) (32\%). Police in general is deemed to be prone to bribery (26\%) as well as court system (21\%). Less frequently respondents would mention medicine $(17 \%)$, large business $(14 \%)$ and education (13\%). Meanwhile, main sectors of corruption "market", namely allocation of funds from the budget and management of state property of various forms, constitute a latent zone for public awareness while making up for the primary part of corruption market (Note 5).

We'll try to fund out the causes of this complex and multifaceted phenomenon and what counteractions have been efficient in many countries of the world.

Scientists and experts working on this problem aver that causes of corruption are numerous and can be structured into the following groups: social and economic causes, political causes, organizational causes, legal causes, as well as cultural and ethical causes.

\subsection{Social and Economic Causes}

The main consistent pattern that was identified in course of analyzing spatial characteristics of corruption is dependency of corruption level in a given country upon the level of its economic development.

Availability of natural resources in a given country (mineral, forest, aquatic) factors its level of corruption to a certain extent as well. However, its importance can be estimated two ways. On the one hand, availability of rich natural resources is the basis of a country's economic development, which, in its turn might help reduce corruption. On the other hand, mineral wealth is a powerful stimulus, a nourishing soil for corruption, since it provokes illegal actions on the part of individuals who wish to gain access to this wealth. Besides, attitude to natural resources in a state that initially possess it in abundance (they are given by the nature, not gain though 
hard work) is often a consumer's attitude which conduces corruption as well. We can see it in our own country which has a problem of a "slant" towards the raw materials sector. This way, abundance of natural resources in a country can be considered as a factor of corruption to a certain extent (Note 6).

The main economic source of corruption (in Russia as well) are processes taking place in the "grey" or informal economy. It can be stated with certainty that the share of "grey" economy in the economy of a state directly stipulates the level of corruption in it. Currently experts discuss a phenomenon of "corrupt economy" (Note 7) taking place in our country.

Among the economic causes of corruption are complicated procedures of obtaining a permit; lack of transparency in auctions and reluctance or fear of businessmen to fight for its transparency; failure to follow the current taxation legislation and lack of social control in this area of social relations (Note 8).

Among one of the most important achievements of economic development is educational system. As a rule, an educated society is less tolerant towards various violations of morality and ethics, since it is well aware of its rights and respective obligations of the state. In this regard we can see certain correlation between the educational level of the society and level of corruption in it.

Social ground of corruption is significant gap between the rich and the poor, even more striking against the background of overall poverty and weakness of the state. In the conditions of economic instability and inappropriate social programs aimed to protect and ensure rights and freedom of a Russian citizen, the problem of absence of middle class and exceedingly high share of those below the poverty line become even more glaring. This is one of the factors of ethical and cultural causes of corruption. Greater part of the population does not trust government and its social and economic policy, since in fact it is only those who can do it in illegal ways that can make enough amount of money and maintain adequate standard of living. Unfortunately, we have to state that currently few dozens of individuals in aggregate hold a budget equal to that of the state.

Thus, social and economic factors strongly stipulate corruption and its prevalence in a given state.

\subsection{Political Causes}

Among political factors of corruption we pinpoint peculiarities of political system. Political system of any country can be characterized first of all through its form of government. Democratic regime in a republic (dominating among other forms nowadays, so we chose it for analysis) ensures possibilities and stimuli for corruption and evolvement of its new forms. Strong democratic tradition in the society entailing social and political freedom can be important when we consider corruption. A consistent pattern has been identified: countries that have longer historical experience of democracy are affected by corruption to a lesser extent that the countries that have no such experience or have very short experience (Note 9). Social and political liberties define status of an individual as a citizen of a given state legally authorized to participate in governing and public affairs. High level of such freedom increases probability of publicity of illegal actions and disclosure of corrupt practices as a result. In particular, absence of practical implementation of the right of free access to information in many countries result in fight for information that is in fact fight for accountability of public authorities (Note 10). Besides, real operation of the mentioned freedom enables to establish social and legal control under which certain public authorities, social organizations and officials are legally authorized to observe and inspect activities of certain citizens and legal entities in order to ascertain compliance with requirements; if any violations are found they are entitled to inform state authorities and (or) the public and submit motions or recommendations that the parties at fault be made liable (Note 11). The necessary term here is transparency. This way the problem is reduced to efficiency of public authorities system, quality of state administration and, certainly, kneading moral values among the public authorities at all levels.

The author deems that one of the causes of prevalent corruption in Russia is deformations of political system and state authority. Engagement of state structures into mechanisms of capital allocation and flows of commodity and money in which they actively participate without setting rules of the market game as it happens in developed foreign states where corruption is minimized, but acting as a participant of these processes pursuing individual interests is the most significant cause of corruption in Russia in our opinion.

\subsection{Organizational and Institutional Causes}

It is widely known that power and control over corruption are interrelated. Corruption is a sign of weak power and unskilled management. The gist of managerial impotence and evolvement of corruption is lack of clear institutional organization, detailed regulation of operation, control systems and liability for violations (Note 12).

But if we consider organizational and institutional causes in greater detail, we can distinguish other components within its structure, for example, corruption defects of legal regulation. 
Defects and gaps in statutes and other regulations work as prerequisites for abuse; i.e. so-called "corruption niches" are one of the terms for further spread of corruption. Absence of direct effect provisions in statutes enables public officials to interpret law to their benefit based on inter-institutional regulations or make arbitrary decisions without references to a certain regulation.

There are many signs of laws' potential to give rise to corruption, in particular such as: multiple options with disposition of legal regulations, vast opportunities for institutional and local lawmaking, absence of contest and auction procedures, absence of detailed bans and restrictions for federal and municipal officers in exercising their powers, absence of control, including social control over public authorities. Significant "corruption niches" can be found nearly in all regulations related to permit system and resources allocation. Certain provisions were inculcated into statutes and other regulations though lobbying on the part of the respective influence groups. Corruption is becoming a norm, rather than an exception among the political and economic elite as well. This means that law enforcement agencies sunk in bribery to no lesser extent are on the one hand too weak to counteract institutional corruption, on the other hand in matters like that they are not only and not completely subordinated to law. The powerful aggregation (bureaucracy - business - organized criminality) named "iron triangle" lives under its own laws (Note 13).

Second is law enforcement practice.

Real practice of enforcing law and institutional regulations, in particular pertaining to permit system is often used to create artificial administrative barriers for citizens and business to increase income from corruption.

Engaging private companies to prepare necessary documents to solve an issue through an institution has become a widely used practice. In recent years deadlines for perusing documents and fees paid to private intermediaries for overcoming administrative barriers have become much higher.

Grassroots corruption is attractive because while it poses minimum amount of risk for both parties, it has a specific value not only for the one who receives the bribe, but for the one who offers it as well. A bribe helps solve many routine problems (residential registration, executing various documents of title to property, obtaining permits and licenses) and enables to commit minor violations of laws and instructions.

Far-reaching grassroots corruption is very dangerous since, first of all, it creates a conducive psychological atmosphere for other forms of corruption, and second, it nurtures vertical corruption. The latter gives rise to organized criminal communities.

Grassroots corruption penetrates all areas where a citizen faces the necessity to address the state and, on the contrary, the state funds it necessary to interfere with a citizen's affairs. The main areas where grassroots corruption reaches the greatest scale in Russia are residential and public services, taxation, customs and law enforcement.

Third is inefficiency of counteractions. Despite that law enforcement agencies implement counteractions, their efficiency is low and results are insignificant. This conclusion is evidenced by statistics.

Manifestations of corruption are multifaceted; they take different shares, transform and evolve, taking new objectives in political, economic, managerial and other areas.

We must take into account that crimes of this type have always been latent, so the statics shows only the tip of the iceberg, does not reflect the true state of affairs and does not yield the true account of extent of bribery and trading of influence, not to mention other corruption-related crimes and defaults.

Experts estimate that only about one percent of corruption-related crimes are identified and registered. Moreover, mostly it is only lower echelon officers that are ever made liable, while the higher echelon where corruption is spread to no lesser extent is almost never affected. This low delivery in identifying corruption crimes against the background of activation among law enforcement agencies signifies only one thing - growing prevalence of corruption which the current law enforcement system cannot adequately counteract.

Vast affection by corruption of structures that must counteract it makes up for significant decrease in efficiency of counteractions. Certain employees of law enforcement, surveillance and controlling authorities involved with corruption schemes can disable search, investigation and inspection work, in particular if they take high positions, reducing efforts of large teams of professionals to nothing, aggravating mistrust of citizens to public officials, undermining their authority and prestige of state service.

Fourth, investigative journalism is underdeveloped. Often "independent anticorruption investigation" are papers ordered and paid for by financial and industrial influence groups aimed to "expose" economic competitors and debunk political ones. Active civil position of a journalist that does not fit within the aforementioned scheme and 
is often combated by corrupt officials that go to all lengths to compromise or somehow "neutralize" such journalist.

This way, taking into account the aforementioned circumstances efficiency of counteractions on the part of state structures and civil society institutes is exceedingly low and inadequate compare to scope of this phenomenon and threats to national safety of Russia.

\subsection{Ethical and Cultural Factors}

The legal system needs to be changed from within and not through the introduction, even ideal, though logically structured as in nature so in content, but not by the norms misunderstood and not supported by people. In other words, we think cultural reasoning is sometimes even more important than any others, especially of we are talking about Russia (Note 14). Moral degeneration of the society followed by manifestations of base feelings and instincts in social, political and public spheres largely conduce prevalence of corruption. Current social mind of Russian citizens contains two interrelated social attitudes.

One of them is corruption dependency, i.e. corruption is considered an integral part of life in Russia. The second attitude can be characterized as readiness for corruption (Note 15). The latter means psychological proneness to solve various issues though bribery. In our opinion a current Russian citizen cannot be blamed for it. The state and the society have created the terms of work, running business and options to solve various issues that do not enable Russian citizens to act as law directs. It is caused by bureaucracy, administrative barriers, and lack of transparency in operation of public authorities. As E. A. Postriganov notes, another important criminogenic factor that conduces corruption is fall of morality. Policy of wealth accumulation popular in the 90s of XX century resulted in prevalence of psychology of acquisitiveness, strife to gain at any rate, including at the rate of state service interests, in spite of legitimate interests of the majority of population (Note 16). In combination with other phenomena, when financial need compels, political instability prompts and legal confusion conduces violations, moral values in the mind of certain public officials (if any) cannot combat corruption.

Since no adequate character building work is done among the population, wealth, no matter how it was acquired, becomes the standard of human values and gaining profit at any rate becomes the main life principle. Idol for young people is no longer a teacher and a doctor, a scientist and an architect, i.e. those who create material and moral values for the state and the society. Their idols are financial dealers and businessmen from criminal world. Propaganda of violence and materialism, ignorant attitude to morality and traditional Russian values - generous service for the Motherland, conscience and justice, mutual support and collectivity by mass media conduce corruption as well. Young people are inspired by characters from TV shows who are not bothered by morality and spiritual values, who are self-assured, cynical, cunning and unscrupulous, who eliminate their competitors dispassionately, despise the weak and ignore others' interests.

Until radical changes occur in this sphere, corruption counteraction brings no results, since the moral ground that nurtures corruption and breeds tolerance towards it remains unchanged.

Population gets used to corruption, does not see it as evil only and even takes it as a behavioral norm in the contemporary society. Significant portion of young people pursue a high position in a state body as their career goal to ensure themselves launch environment for material gain and adequate standard of life. Public opinion justifies any means to achieve one's goal, including illegal and immoral ones. So far neither the state nor the society have given young people any other examples, thus literally nurturing the generation for which cynical attitude to interests of Russia and ignorance of its fellow men are widely spread.

Thus, culture, religion, mentality (world outlook) and morality of the society as aggregate conduce to proneness of a state to corruption.

\section{Conclusion}

Thus, corruption as a phenomenon has more than one goal and is brought about by a multilayered complex within which we can pinpoint social and economic, political, ethical, cultural and other causes. Without consistent counteraction corruption spreads. That's why development and implementation of anticorruption policy is becoming more natural for any state. The policy is a system of interrelated priorities and counteractions that includes political, organizational, economic, ideological and legal components. Anticorruption system must be implemented on the highest level of national political management in close cooperation with institutes of civil society. The global community has a chance to minimize manifestations of corruption only of anticorruption policy is successfully implemented. In this case as it was mentioned earlier, the choice of anticorruption strategy must be grounded in research of social, cultural and historical context. 


\section{References}

Causes and terms that bring about corruption in the contemporary Russian Federation. Retrieved from http://moluch.ru/conf/law/archive/43/2872

Chumanov, A. V. (2007). Anticorruption policy in Russia and its priorities. Legitimacy and law, 61-67.

Corruption: Fight is getting hotter, bribes are getting higher. Retrieved from http://korrossia.ru/actual/10764 -korrupciya-borba-krepchaet-vzyatka-narastaet.html

Global Corruption Report 2003. Transparency International. Retrieved from http://www.globalcorruption report.org

Korchagin, A. G., Ivanov, A. M., \& Shcherbakov, A. V. (1999). Economic crimes, 60. Vladivostok.

Kuzmin, N. A. (2009). On the issue of notion and nature of corruption. Russian investigator, (24), 23.

Luneev, V. V. (2000). Corruption: political, economic, organizational and legal problems. State and law, (4), 106.

Miroshnichenko, O. I. (2014). Legal mentality as a means to overcome formal legal nihilism in Russian society. Asian Social Science, 10(19), 169-172. http://dx.doi.org/10.5539/ass.v10n19p169

Nomokonov, V. A. (2004). Corruption around the world and international strategy to combat it. Vladivostok, 27.

Nomokonov, V. A. (2007). Problems of anticorruption policy evolvement in Russia (p. 539). State policy combating corruption and "grey" economy in Russia. Moscow.

Postriganov, E. A. (2009). Organizing corruption counteraction in the Russian Federation. Russian customs policy in the Far East, 3(48), 69-72.

Sulima, I. I., \& Sulima, E. V. (2001). Nature of corruption and its evolvement (pp. 253-259). Corruption in state authorities: nature, counteractions, international cooperation. N. Novgorod.

Treisman, D. (2000). The causes of corruption a cross-national study. Journal of Public Economics, (76), 456-457. http://dx.doi.org/10.1016/S0047-2727(99)00092-4

\section{Notes}

Note 1. URL:1//moluch.ru/conf/law/archive/43/2872.

Note 2. Kuzmin, 2009.

Note 3. URL:1//korrossia.ru/actual/10764-korrupciya-borba-krepchaet-vzyatka-narastaet.html

Note 4. URL:1//korrossia.ru/actual/10764-korrupciya-borba-krepchaet-vzyatka-narastaet.html

Note 5. URL:1//korrossia.ru/actual/10764-korrupciya-borba-krepchaet-vzyatka-narastaet.html

Note 6. Nomokonov, 2004.

Note 7. Nomokonov.

Note 8. Sulima I. I., \& Sulima E. V., 2001.

Note 9. Chumanov, 2007.

Note 10. Treisman, 2000.

Note 11. Korchagin, Ivanov, \& Shcherbakov, 1999.

Note 12. URL: www.globalcorruptionreport.org

Note 13. Nomokonov, 2007.

Note 14. Miroshnichenko, 2014.

Note 15. Luneev, 2000.

Note 16. Postriganov, 2009.

\section{Copyrights}

Copyright for this article is retained by the author(s), with first publication rights granted to the journal.

This is an open-access article distributed under the terms and conditions of the Creative Commons Attribution license (http://creativecommons.org/licenses/by/3.0/). 